\title{
In vivo ligation of glucocorticoid-induced TNF receptor enhances the T-cell immunity to herpes simplex virus type 1
}

\author{
Soojin La ${ }^{1}$, Eunhwa $\mathrm{Kim}^{1}$ and \\ Byungsuk Kwon ${ }^{1,2}$ \\ ${ }^{1}$ The Immunomodulation Research Center and \\ Department of Biological Science \\ University of Ulsan \\ Ulsan 680-749, Korea \\ ${ }^{2}$ Corresponding author: Tel, 82-52-259-2860; \\ Fax, 82-52-259-2740; E-mail, bkwon@mail.ulsan.ac.kr
}

Accepted 6 May 2005

Abbreviations: DLN, draining lymph node; $g \mathrm{~B}$, glycoprotein $\mathrm{B} ; \mathrm{gD}$, glycoprotein D; GITR, glucocorticoid-induced tumor necrosis factor receptor; GVHD, graft-versus-host disease; HSV-1, herpes simplex virus type 1

\begin{abstract}
GITR (glucocorticoid-induced TNF receptor) is a recently identified member of the TNF receptor superfamily. The receptor is preferentially expressed on $C D 4^{+} C D 25^{+}$regulatory $T$ cells and GITR signals break the suppressive activity of the subset. In this study, we wanted to reveal the in vivo function of GITR in herpes simplex virus type 1 (HSV-1) infection. A single injection of anti-GITR mAb (DTA-1) immediately after viral infection significantly increased the number of CD4 ${ }^{+}$and $C D 8^{+} \mathrm{T}$ cells expressing CD25, an activation surface marker, and secreting IFN- $\gamma$. We confirmed these in vivo observations by showing ex vivo that re-stimulation of $C D 4^{+}$or $C D 8^{+} \mathrm{T}$ cells with a $\mathrm{CD}^{+}$or $\mathrm{CD} 8^{+}$T-cell-specific HSV-1 peptide, respectively, induced a significant elevation in cell proliferation and in IF $N-\gamma$ secretion. Our results indicate that GITR signals play a critical role in the T-cell immunity to HSV-1.
\end{abstract}

Keywords: GITR; HSV-1; gB; gD; Th1 cell; CTL

\section{Introduction}

GITR (glucocorticoid-induced TNF receptor) was originally identified by comparing untreated and dexamethasone-treated murine T-cell hybridoma cells (Nocentini et al., 1997). Later, human orthologue and its ligand were cloned by searching an EST (expressed sequence tag) database (Gurney et al., 1999; Kwon et al., 1999a; 1999b; 2003). GITR expression is up-regulated on $T$ cells after activation, and a high level of GITR is constitutively expressed on $\mathrm{CD}^{+}$ $\mathrm{CD}^{+} 5^{+}$regulatory T cells (McHugh et al., 2002; Shimizu et al., 2002). Initial characterization of GITR functions revealed that the receptor could inhibit T-cell receptor (TCR)-induced apoptosis in the $T$ cell hybridoma that was used to clone the GITR gene (Nocentini et al., 1997). This was confirmed in a human T cell line (Gurney et al., 1999). Consistently, GITR-deficient mouse T cells exhibited a higher capacity to proliferate in response to TCR stimulation but underwent higher levels of activation-induced cell death (Ronchetti et al., 2002). In $\mathrm{CD}^{+} \mathrm{CD} 25^{+}$regulatory T cells, GITR signals have been shown to abrogate their suppressive function (McHugh et al., 2002; Shimizu et al., 2002). However, recent studies have demonstrated that GITR functions as a costimulatory molecule for conventional $\mathrm{T}$ cells in vitro (Ji et al., 2004; Kanamaru et al., 2004; Kohm et al., 2004; Muriglan et al., 2004; Ronchetti et al., 2004) and that GITR-deficient mouse $\mathrm{CD} 4^{+} \mathrm{CD} 25^{+}$regulatory $T$ cells were able to exert the suppressive activity on conventional $\mathrm{CD}^{+}{ }^{+} \mathrm{T}$ cells as equally as wild-type $\mathrm{CD} 4^{+} \mathrm{CD} 25^{+}$regulatory T cells (Ronchetti et al., 2002).

The in vivo function of GITR remains largely to be defined. In this study, we wanted to reveal the in vivo function of GITR in an HSV-1 infection model. Our data demonstrated that ligation of GITR markedly increased the T-cell immunity to HSV-1.

\section{Materials and Methods}

Mice and peptides

Female Balb/c mice, 6-8 wk of age, were purchased from Orient (Seoul, Korea). The HSV-1 glycoprotein $D_{246-261}\left(\mathrm{gD}_{246-261}\right.$ : APYTSTLLPPELSETP) peptide was described previously (Grammer et al., 1990) and was shown to be specific for Th1 cells (BenMohamed et al., 2003). The $\mathrm{gB}_{498-505}$ (SSIEFARL) peptide is an immunodominant peptide for $\mathrm{CD}^{+} \mathrm{T}$ cells (Hanke et al., Witmer et al., 1990; Bonneau et al., 1993). The peptides were synthesized by Peptron (Daegen, Korea).

mAbs and flow cytometry

Anti-GITR mAb (DTA-1) was described previously (Shimizu et al., 2002) and purified from ascites. Control rat Ig was purchased from Sigma (St Louis, MO). FITC-anti-CD3, FITC- or phycoerythrin (PE)-anti- 
CD4, FITC- or PE-anti-CD8, PE-anti-CD25, and PEanti-IFN- $\gamma$ mAbs were purchased from BD Biosciences Pharmingen (San Diego, CA). Lymphocytes were stained and analyzed as described previously (Kim et al., 2005). Intracellular staining for IFN- $\gamma$ was performed according to the manufacturer's instruction (BD Biosciences Pharmingen).

\section{Virus and infection}

The KOS strain of HSV-1 was used in this study. For the production of the virus stock supernatant, the virus-infected Vero cell cultures were centrifuged at $1,500 \mathrm{rpm}$ and filtered with a $0.45-\mu \mathrm{m}$ mesh filter to remove cellular debris. The viruses were titrated using the end-point dilution method. Balb/c mice were inoculated with $5 \times 10^{5} \mathrm{PFU}$ of HSV-1 injected s.c. into each hind footpad. DTA-1 or control Ig (300 $\mu \mathrm{g}$ per mouse) was i.p. injected immediately thereafter.

A
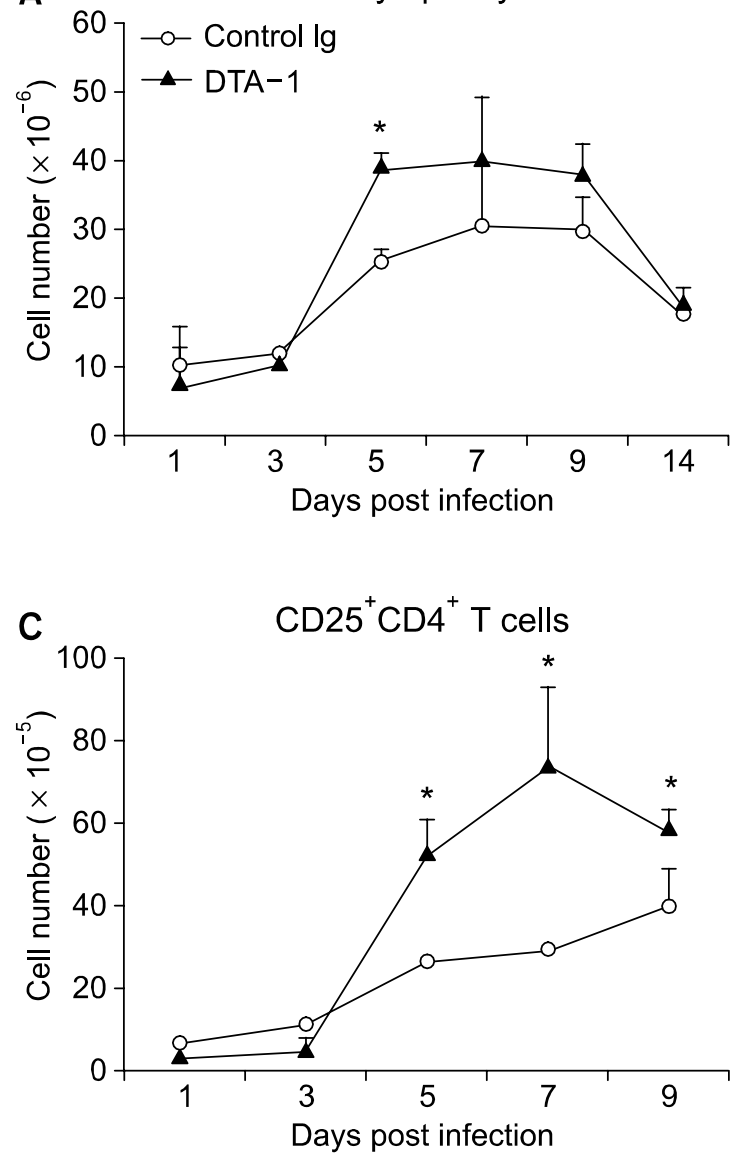

\section{Proliferation assay}

The DLNs were harvested from HSV-1-infected mice and a single cell suspension was prepared in PBS. The cell debris was removed by passing through 70- $\mu \mathrm{m}$ cell strainer (BD Falcon, San Diego, CA). Isolated lymphocytes $\left(5 \times 10^{5}\right)$ were cultured at various concentrations of peptide for $72 \mathrm{~h}$. Proliferation was assessed in triplicate by pulsing with 1 $\mathrm{Ci}\left[{ }^{3} \mathrm{H}\right]$ thymidine for $12 \mathrm{~h}$.

\section{ELISA}

IFN- $\gamma$ was measured from culture supernatant, using an ELISA kit (Endogen, Woburn, MA), according to the manufacturer's protocol.

\section{Statistical analysis}

Student $t$ test was used to determine the statistical significance of differences between experimental groups.
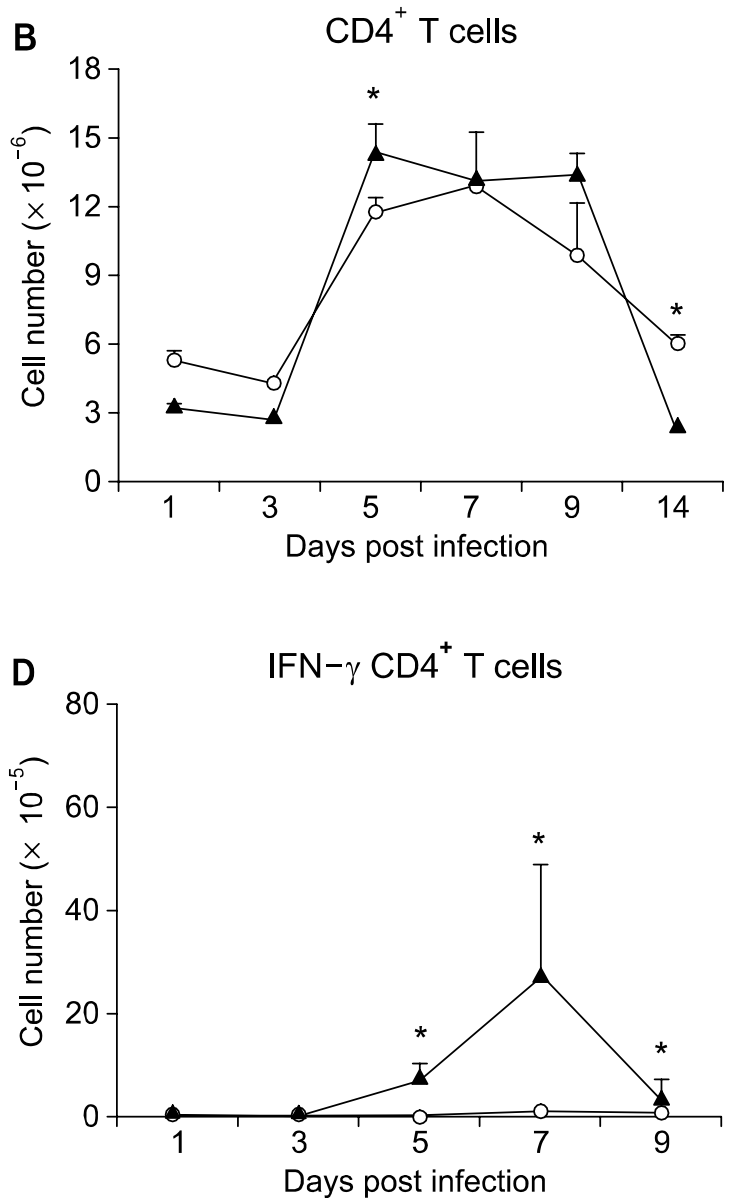

Figure 1. Ligation of GITR activates $\mathrm{CD4}^{+} \mathrm{T}$ cells after HSV-1 infection. Mice were infected in the hind foodtpad with $5 \times 10^{\circ} \mathrm{PFU}$ of HSV-1. DTA-1 or control lg (300 $\mu \mathrm{g}$ per mouse) was i.p. injected immediately thereafter. (A) The number of total lymphocytes isolated from the DLN. (B) $C D 4^{+}$T cells derived from the DLN were counted by staining the DLN cells with anti-CD3 and anti-CD4. (C) Activated $\mathrm{CD}^{+} \mathrm{T}$ cells were counted by staining the DLN cells with anti-CD4 and anti-CD25. (D) The DLN cells were stained for CD4 combined with intracellular staining for IFN- $\gamma$. Data are shown as mean $\pm S D$ of $n=3$. ${ }^{*} P<0.05$, between the 2 groups at the indicated time points. 


\section{Results and Discussion}

Agonistic anti-GITR antibody (DTA-1) has been shown to abolish the immunosuppressive activity of $\mathrm{CD} 4^{+}$ $\mathrm{CD} 25^{+}$regulatory $\mathrm{T}$ cells (Shimizu et al., 2002). Administration of DTA-1 exacerbates experimental autoimmune encephalomyelitis (Kohm et al., 2004) and acute graft-versus-host disease (GVHD) (Muriglan et al., 2004). Using this agonistic mAb, we examined its effect on the immune response to HSV-1 infection. The kinetics for the expansion of total lymphocytes and $\mathrm{CD4}^{+} \mathrm{T}$ cells was similar in the DLN of DTA-1and control Ig-treated mice at all the time points investigated except for 5-day postinfection (Figure $1 \mathrm{~A}$ and $\mathrm{B}$ ). We next counted activated $\mathrm{CD} 4^{+} \mathrm{T}$ cells by analyzing the expression of CD25 on the cell surface of $\mathrm{CD}^{+}{ }^{+} \mathrm{T}$ cells and by staining intracellular IFN- $\gamma$ that represents effector $\mathrm{T}$ cells more precisely. Both methods showed that a noticeable expansion of activated $\mathrm{CD}^{+} \mathrm{T}$ cells from DTA-1-treated mice began at 5-day postinfection and reached a peak at day 7 (Figure $1 \mathrm{C}$ and $\mathrm{D})$. In comparison with control Ig-treated mice, marked increase in activated $\mathrm{CD}^{+}{ }^{+} \mathrm{T}$-cell numbers was observed in DTA-1-treated mice between day 5 and day 9 after infection (Figure $1 \mathrm{C}$ and D). Although activated $\mathrm{CD}^{+} \mathrm{T}$ cells expressing CD25 existed in the

A
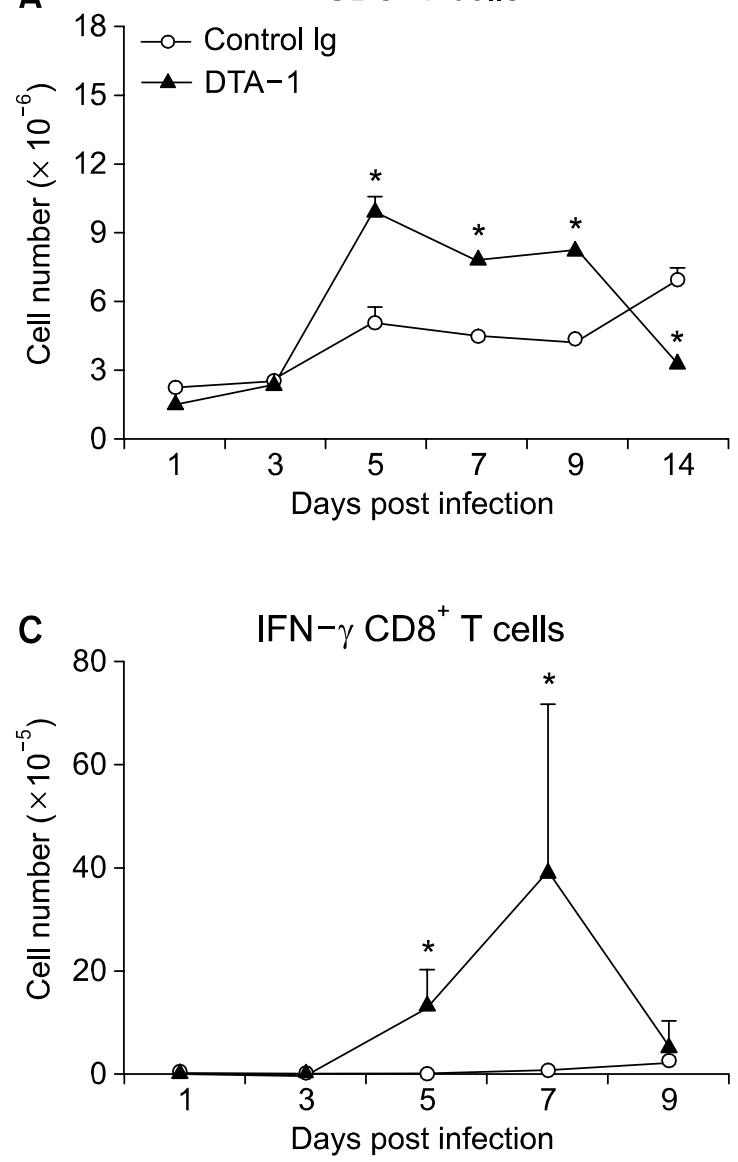

DLN of control Ig-treated mice, production of intracellular IFN- $\gamma$ in $\mathrm{CD} 4^{+} \mathrm{T}$ cells was barely detectable (Figure 1D). Our results indicate that DTA-1 potently induced the expansion of effector $\mathrm{CD} 4^{+} \mathrm{T}$ cells to viral antigens.

Unlike $\mathrm{CD}^{+} \mathrm{T}$ cells, $\mathrm{CD}^{+} \mathrm{T}$-cell numbers were significantly greater between day 5 and day 9 in the DLN of DTA-1-treated mice compared with those of control Ig-treated mice (Figure 2A). At day 14, the number of both $\mathrm{CD} 4^{+}$and $\mathrm{CD}^{+}{ }^{\mathrm{T}}$ cells of DTA-1treated mice was significantly reduced, presumably as a result of activation-induced death (Figure $1 \mathrm{~A}$ and $2 A)$. The kinetics of activated CD8+ T-cell expansion was parallel to that of activated CD4+ T-cell expansion (Figure 2C and D). We did not detect activation of $\mathrm{CD} 4^{+}$and $\mathrm{CD} 8^{+} \mathrm{T}$ cells in non-draining lymph nodes in either group after HSV-1 infection (data not shown). Taken together, our results suggest that in vivo ligation of GITR can significantly increase activation of both $\mathrm{CD}^{+}$and $\mathrm{CD} 8^{+}{ }^{-}$cells after HSV-1 infection.

To directly verify whether ligation of GITR induces the generation of antigen-specific $T$ cells, the DLNderived T-cell responses to peptide epitopes were examined ex vivo 7 days after infection. Our results showed that the Th1-specific $\mathrm{gD}_{246-261}$ peptide vigo-

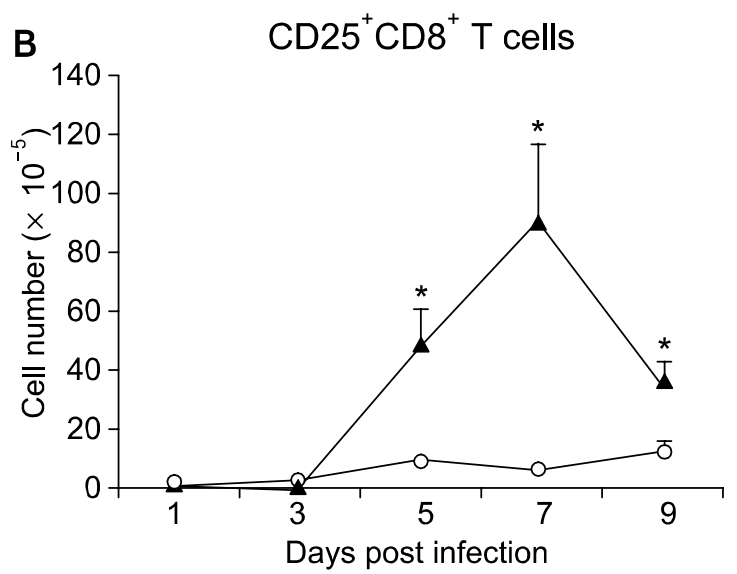

Figure 2. Ligation of GITR activates $\mathrm{CD} 8^{+} \mathrm{T}$ cells after HSV-1 infection. Mice were infected in the hind foodtpad with $5 \times 10^{5}$ PFU of HSV-1. DTA-1 or control $\lg (300 \mu \mathrm{g}$ per mouse) was i.p. injected immediately thereafter. (A) $\operatorname{CD} 8^{+} T$ cells isolated from the DLN were counted by staining the DLN cells with anti-CD3 and anti-CD8. (C) Activated $\mathrm{CD} 8^{+} \mathrm{T}$ cells were counted by staining the DLN cells with anti-CD8 and anti-CD25. (D) The DLN cells were stained for CD8 combined with intracellular staining for IFN- $\gamma$. Data are shown as mean \pm SD of $n=3$. ${ }^{*} P<0.05$, between the 2 groups at the indicated time points. 
A

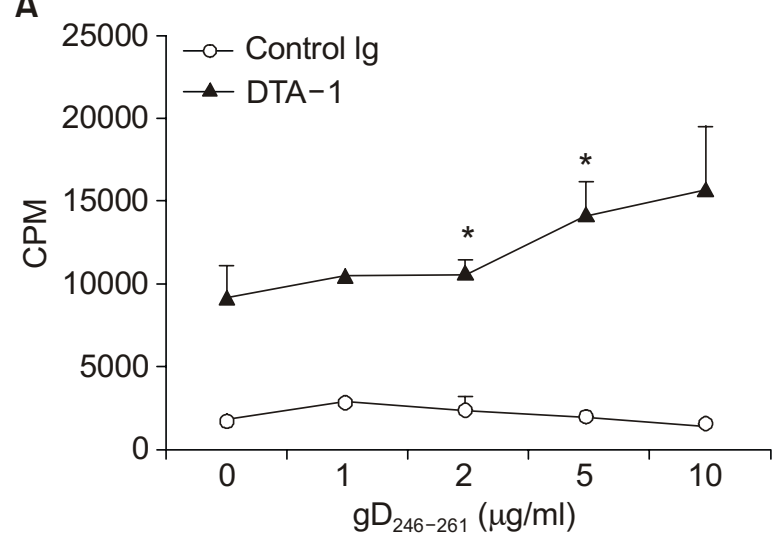

C

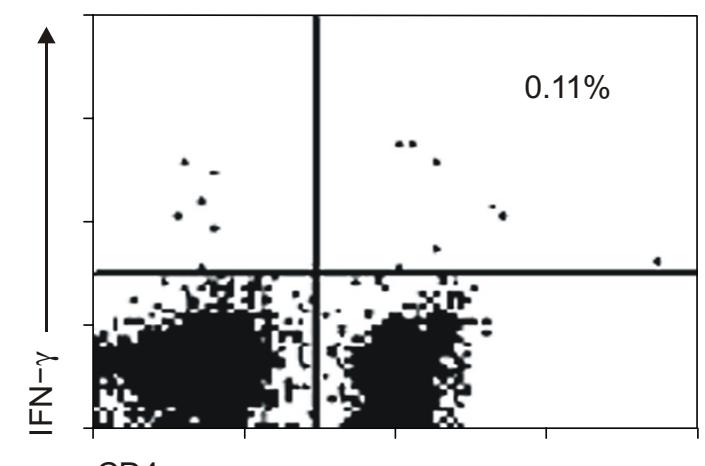

B

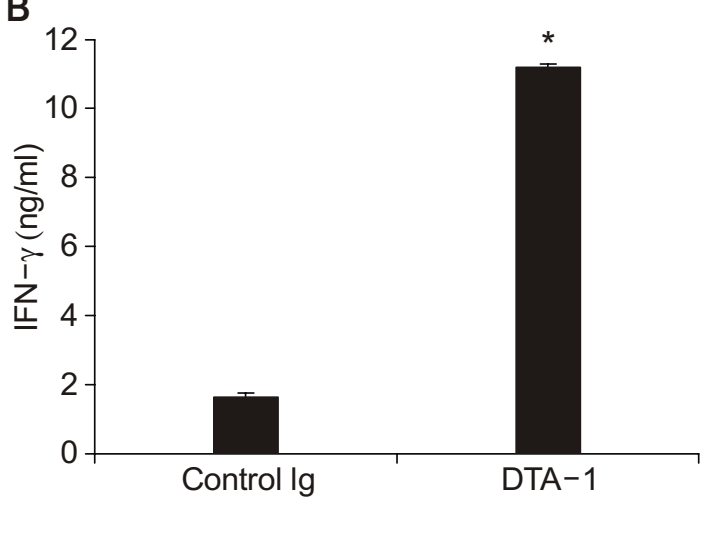

DTA-1

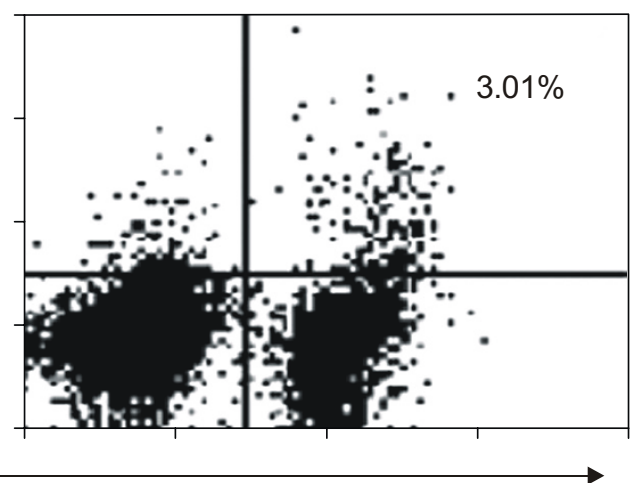

Figure 3. Increase in $\mathrm{gD}_{246-261}$-specific $\mathrm{T}$ cells. (A) The cells isolated from the DLN at 7-day postinfection were stimulated with various concentrations of $\mathrm{gD}_{246-261}$ peptide for $72 \mathrm{~h}$. Proliferation was assessed in triplicate by pulsing with $1 \mathrm{Ci}^{3} \mathrm{H}$ ]thymidine for the last $12 \mathrm{~h}$. (B) After the DLN cells were stimulated with $10 \mu \mathrm{g}$ of $\mathrm{gD}_{246-261}$ peptide for $24 \mathrm{~h}$, supernatants were collected and assayed for IFN- $\gamma$ by ELISA. (C) The DLN cells were stimulated with $10 \mu \mathrm{g}$ of $\mathrm{gD}_{246-261}$ peptide for $6 \mathrm{~h}$ and were stained for CD4 combined with intracellular staining for IFN- $\gamma$. ${ }^{*} P<$ 0.05 , between the 2 groups.

rously stimulated the proliferation of $T$ cells from DTA-1-treated mice in a dosage-dependent manner (Figure $3 \mathrm{~A}$ ). In our experimental conditions, $T$ cells of control Ig-treated mice had a minimal proliferation. In consistence, peptide-stimulated $T$ cells of DTA-1treated mice secreted high levels of IFN- $\gamma$ compared with those of control Ig-treated mice (Figure 3B). Intracellar IFN- $\gamma$ staining analysis demonstrated that DTA-1-treated mice had approximately 30 -fold increase in the frequency of $\mathrm{gD}_{246-261}$ peptide-specific $\mathrm{CD}^{+} \mathrm{T}$ cells as compared with control Ig-treated mice (Figure $3 \mathrm{C}$ ). Similarly, the $\mathrm{CD}^{+} \mathrm{T}^{\mathrm{T}}$ cell-specific $\mathrm{gB}_{498-505}$ peptide induced such a vigorous in vitro response as the $\mathrm{gD}_{246-261}$ peptide did (Figure 4). These data indicate that in vivo GITR stimulation can augment the expansion of antigen-specific $\mathrm{CD} 4^{+}$and $\mathrm{CD} 8^{+} \mathrm{T}$ cells after HSV-1 infection.

The expression pattern of GITR suggests that GITR may be involved in functions of a variety of immune cells, including $T$ cells, B cells and macrophages (Shimizu et al., 2002). In agreement of our data presented in this report, results from other in vivo studies have shown that GITR stimulation increases Th1 autoreactivity in experimental autoimmune encephalomyelitis (Kohm et al., 2004) and $\mathrm{CD}^{+} \mathrm{T}$ cell-mediated acute GVHD (Muriglan et al., 2004). Ligation of GITR also has been shown to markedly enhance the $\mathrm{CD} 8^{+} \mathrm{T}$-cell activity in chronic GVHD (manuscript in submission). It is possible that several mechanisms of action underlying the in vivo observations are operative; GITR signals either activate the $\mathrm{CD} 4^{+}$and $\mathrm{CD} 8^{+} \mathrm{T}$ cells through depressing the immunosuppressive activity of $\mathrm{CD} 4^{+} \mathrm{CD} 25^{+} \mathrm{T}$ cells (Kohm et al., 2004) or directly activate CD25 $\mathrm{CD}^{+}$or $\mathrm{CD}^{2} 5^{-} \mathrm{CD} 8^{+}$conventional T cells (Muriglan et al., 2004; manuscript in submission). In a chronic GVHD that is mediated by Th2 cells, in vivo engagement of GITR prevents donor $\mathrm{CD}^{+} \mathrm{T}$-cell tolerance and the subsequent activation of donor $\mathrm{CD} 8^{+} \mathrm{T}$ cells and Th1 $\mathrm{CD}^{+} \mathrm{T}$ cells shifts chronic GVHD toward acute GVHD (manuscript in submission).

The main finding presented in this report is to 

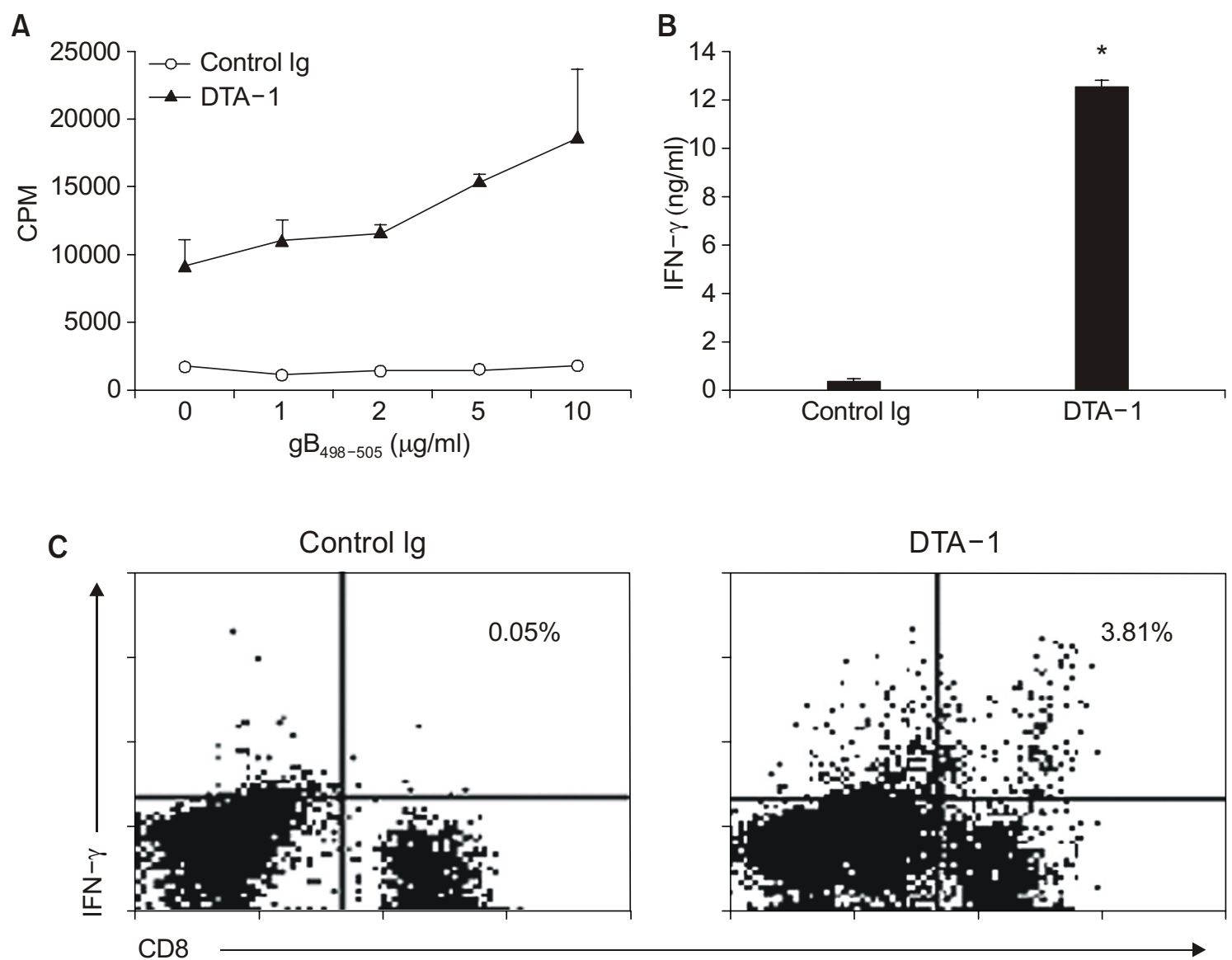

Figure 4. Increase in $\mathrm{gB}_{498-505}$-specific $T$ cells. (A) The cells isolated from the DLN at 7-day postinfection were stimulated with various concentrations of $\mathrm{gB}_{498-505}$ peptide for $72 \mathrm{~h}$. Proliferation was assessed in triplicate by pulsing with $\left.1 \mathrm{Ci}^{3}{ }^{3} \mathrm{H}\right]$ thymidine for the last $12 \mathrm{~h}$. (B) After the DLN cells were stimulated with $10 \mu \mathrm{g}$ of $\mathrm{gB}_{498-505}$ peptide for $24 \mathrm{~h}$, supernatants were collected and assayed for IFN-- $\gamma$ by ELISA. (C) The draining lymph node cells were stimulated with $10 \mu \mathrm{g}$ of $\mathrm{gB}_{498-505}$ peptide for $6 \mathrm{~h}$ and were stained for CD8 combined with intracellular staining for IFN- $\gamma$. ${ }^{*} P<0.05$, between the 2 groups.

reveal in vivo the involvement of a GITR co-stimulatory pathway in viral infection. To be equally important, we provide a possibility of GITR stimulation as an adjuvant in elevating the immune response to efficiently remove viral infection. Our results demonstrated that ligation of GITR induced approximately 30 -fold and 80 -fold increase in the frequency of antigen-specific $\mathrm{CD} 4^{+}$Th1 cells and $\mathrm{CD}^{+} \mathrm{T}$ cells, respectively (Figure 3 and 4 ). It seems that in vivo ligation of GITR removes HSV-1 viruses from the infection site rapidly (our preliminary data). Since the T-cell response takes an action against viruses 5-7 days after infection, the rapid kinetics for the viral removal indicates that GITR signals may be important for anti-viral activities mediated by other cells (e.g., macrophages, dendritic cells, NK cells, and residential cells in the infection site) than $T$ cells. Therefore, this adjuvant effect of anti-GITR mAb may be critical in removing viruses by triggering the innate immunity. In sum, our data suggest a possibility that in vivo ligation of GITR may be effective in removing the primary viral infection.

\section{Acknowledgement}

This work was supported by grants from University of Ulsan (2003-0087) and the SRC Fund to the IRC from KOSEF and the Korean Ministry of Science and Technology.

\section{References}

BenMohamed LB, Bertrand G, McNamara CD, Gras-Masse $\mathrm{H}$, Hammer J, Wechsler SL, Nesburn AB. Identification of novel immunoldominant $\mathrm{CD} 4^{+}$Th1-type T-cell peptide epitopes from herpes simplex virus glycoprotein $D$ that confer protective immunity. J Virol 2003;77:9463-73

Bonneau RA, Salvucci LA, Johnson DC, Tevethia SS. Epitope specificity of $\mathrm{H}-2 \mathrm{~K}^{\mathrm{b}}$-restricted, HSV-1-, and HSV-2cross-reactive cytotoxic T lymphocyte clones. Virology 1993; 
$195: 62-70$

Grammer SF, Sette A, Colon S, Walker L, Chesnut R. Identification of an HSV-1/HSV-2 cross-reactive T cell determinant. J Immunol 1990;145:2249-53

Gurney AL, Masters SA, Huang A, Huang RM, Mark M, Baldwin DT, Gray AM, Dowd P, Bush PJ, Helden S, Schow P, Goddard AD, Wood WI, Baker KP, Godowski PJ, Ashkenazi A. Identification of a new member of the tumor necrosis factor family and its receptor, a human ortholog of mouse GITR. Curr Biol 1999;9:215-18

Hanke T, Graham FL, Reosenthal KL, Johnson DC. Identification of an immunodominant cytotoxic T-lymphocyte recognition site in glycoprotein B of herpes simplex virus by using recombinant adenovirus vectors and synthetic peptides. J Virol 1991;65:1177-86

Ji H-b, Liao G, Faubion WA, Abadia-Molina AC, Cozzo C, Laroux FS, Canton A, Terhosrst C. Cutting edge: The natural ligand for glucocorticoid-induced TNF-related protein abrogates regulatory T cell suppression. J Immunol 2004;172: 4686-90

Kanamaru F, Youngnak P, Hashiguchi M, Nishioka T, Takahashi T, Sakaguchi S, Isikawa I, Azuma M. Costimulation via glucocorticoid-induced TNF receptor in both conventional and $\mathrm{CD}^{+} 5^{+}$regulatory $\mathrm{CD}^{+} \mathrm{T}$ cells. J Immunol 2004;172: 7306-14

Kim J, Choi WS, La S, Suh J-H, Kim B-S, Cho HR, Kwon BS, Kwon, B. Stimulation with 4-1BB (CD137) inhibits chronic graft-versus-host disease by inducing activation-induced cell death of donor $\mathrm{CD}^{+}$T cells. Blood 2005;105:2206-13

Kohm AP, Williams JS, Miller SD. Cutting edge: Ligation of the glucocorticoid-induced TNF receptor enhances autoreactive $\mathrm{CD}^{+}{ }^{+} \mathrm{T}$ cell activation and experimental autoimmune encephalomyelitis. J Immunol 2004;172:4686-90

Kwon B, Yu KY, Ni J, Yu GL, Jang IK, Kim YJ, Xing L, Liu D, Wang SX, Kwon BS. Identification of a novel activation-induced protein of the tumor necrosis factor receptor superfamily and its ligand. J Biol Chem 1999a;274:6056-61

Kwon B, Youn B-S, Kwon BS. Functions of newly identified members of the tumor necrosis factor receptor/ligand superfamilies in lymphocytes. Curr Opin Immunol 1999b;10:340-5

Kwon B, Kim B-S, Cho HR, Park J-E, Kwon BS. Involvement of tumor necrosis factor receptor superfamily (TNFRSF) members in the pathogenesis of inflammatory diseases. Exp Mol Med 2003;35:8-16

McHugh RS, Whitters MJ, Piccirillo CA, Young DA, Shevach EM, Collins M, Byrne MC. $C D 4^{+} \mathrm{CD} 25^{+}$immunoregualtory T cells: gene expression analysis reveals a functional role for the glucocorticoid TNF receptor. Immunity 2002;16:311-23

Muriglan SJ, Ramirez-Montagut T, Alpdogan $O$, van Huystee TW, Eng JM, Hubbard VM, Kochman AA, Tjoe KH, Riccardi C, Pandolfi PP, Sakaguchi S, Houghton AN, van den Brink VRM. GITR activation induces an opposite effect on alloreactive $\mathrm{CD} 4^{+}$and $\mathrm{CD} 8^{+} \mathrm{T}$ cells in graft-versus-host disease. J Exp Med 2004;200:149-57

Nocentini G, Giunchi L, Rochetti S, Krusz LT, Bartoli A, Moraca R, Migliorati G, Riccardi CA. A new member of the tumor necrosis factor/nerve growth factor receptor family inhibits T cell receptor-induced apoptosis. Proc Nat'l Acad Sci USA 1999;94:6216-21

Ronchetti S, Nocentini G, Riccardi C, Pandolfi PP. Role of GITR in activation response of T lymphocytes. Blood 2002; 100:350-2

Ronchetti S, Zollo O, Bruscoli S, Agostini M, Bianchini R, Nocentini G, Ayroldi E, Riccardi C. Frontline: GITR, a member of the TNF receptor superfamily, is costimulatory to mouse T lymphocyte subpopulation. Eur J Immnol 2004;34: 613-22

Shimizu J, Yamazaki S, Takahashi T, Ishida Y, Sakaguchi S. Stimulation of $\mathrm{CD} 25^{+} \mathrm{CD} 4^{+}$regulatory $\mathrm{T}$ cells through GITR breaks immunological self-tolerance. Nat Immunol 2002;3: $135-42$

Witmer LA, Rosenthal KL, Graham FL, Friedman HM, Yee $A$, Johnson DC. Cytotoxic T lymphocytes specific for herpes simplex virus (HSV) studied using adenovirus vectors expressing HSV glycoproteins. J Gen Virol 1990;71:387-96 